\title{
COMPARATIVE ANALYSIS OF THE POVERTY AND PROFITABILITY STATUS OF ADOPTERS AND NON-ADOPTERS OF SUSTAINABLE TAUNGYA FARMING IN OGUN STATE
}

\author{
Abiola M.O., Omidiji D.A., Umeh D.N., Edewor S.A., Adegoke A.O. \\ Federal University of Agriculture, Abeokuta, Nigeria \\ E-mail: abiola.michaelo@pg.funaab.edu.ng
}

\begin{abstract}
This paper investigates the comparative analysis of the poverty and profitability status of adopters and non-adopters of sustainable taungya farming in Ogun State, Nigeria. Multistage sampling procedure was employed for this study. At the first stage, primary data were obtained from a cross-sectional survey of 160 farmers drawn from a purposive selection of two Agricultural Development Programme (ADP) zones; ljebu east and Ilaro zones. The second stage involved the proportionate selection of five blocks from the two ADP zones and at the third stage, four cells each were randomly selected per block. However, only 155 respondents who completed all the questionnaire items were actually used for data analysis. Descriptive statistics, Foster, Greer and Thorbecke Poverty Index, and Budgetary techniques were used for data analysis. Results revealed that $62.5 \%$ of the farmers adopted taungya farming as a form of agroforestry practice, while $34.3 \%$ of the farmers were non-adopters. The estimated relative poverty line was $\$ 2627.59$ per week. Poverty incidence, depth and severity among the adopters were $30.1 \%, 6.8 \%$ and $0.4 \%$ respectively while they were $45.4 \%, 26.3 \%$ and $6.9 \%$ respectively for the non-adopters. The decomposition of the poverty status according to sub-groups was equally shown. The budgetary analysis showed that the net farm income of adopters which was $\$ 249,327 /$ ha was significantly $(p<0.05)$ different from that of the non-adopters which was $\$ 167,391 /$ ha. The study concluded that taungya farming improved adopter's welfare compared to non-adopters and accounted positively in reducing poverty. This study recommended that taungya farming should be encouraged to increase rural farmers' income, and alleviate poverty.
\end{abstract}

\section{KEY WORDS}

Poverty; Foster Greer and Thorbecke Poverty Index; Budgetary techniques; Taungya; Poverty incidence; Poverty depth; and Poverty severity.

The role of taungya farming in supporting the livelihood strategies of the rural poor cannot be overemphasized. The forests are important sources of fuel wood, poles, timber, hunting grounds, and numerous non-timber forest products (AfDB/OECD, 2008). However, the ability of this natural capital to contribute significantly to the socio-economic development of the rural poor is constrained by the dwindling resource base. Taungya farming is the forerunner to agroforestry. It is of Burmese origin and means, "hill" (Taung), "cultivation" (ya) (Nair, 1993). Taungya farming involves the growing of annual or biennial agricultural crops along with the forest species during the early years of establishment of the forest plantation (Jordan et. al., 1992). Taungya farming system preserves the environment and also provides livelihoods for rural communities through a market-driven locally led tree cultivation systems that generate income and build assets. Greening small farms through agro forestry techniques could be the most effective way to increase food availability, reduce poverty, increase carbon sequestration, water efficiency, and at the same time link marginalized farmers with international supply chains. Based on the extensive review of literature from Africa and Asia, it has been demonstrated that the use of agroforestry green growth drivers such as alley-cropping, taungya farming, shifting cultivation, low-tillage farming, resulted in productivity increases of 59 to 179 per cent, and for every 10 per cent increase in farm yields, there is a 7 per cent reduction in poverty in Africa; and more than 5 per cent in Asia (Pretty et al., 2006).

Stripping agroforestry assets is destroying our development opportunities and undermining the potential contribution of agroforestry for the transformation to a low-carbon 
green economy. This impact adversely on the immediate and long-term benefits of taungya farming socially, environmentally and financially. Deforestation and degradation for instance increase sedimentation and decrease water flow, which result in a negative impact on dams, lakes and seas (UNFCCC, 2010). If there are no major changes in policy and in the patterns of investment, the prediction is grim at best. To predict what is likely to happen to the agroforestry sector in the future, it is necessary to link the present livelihood pattern of rural farmers practicing taungya and conventional farming system in order to justify their poverty level.

Production practices based on a continuing and increasing dependence on external inputs, such as chemical fertilizers, pesticides, herbicides and water for crop production need to be altered. They are not sustainable, damage the environment, lead to reduced function of essential ecosystem services, result in the loss of biodiversity (MEA, 2005) and undermine the nutritional and health value of foods. Dung and Dung (2003) assert that the increased dependence on agrochemicals has posed numerous threats on the environment such as health effects on farmers and consumers, pollution of drinking water and decrease in aquaculture. The treatments of these health hazards posed by the use of agrochemicals are cost incurred by the farmers, thereby increasing their poverty rate.

Kuponiyi (2008) also confirmed that most farmers apply agrochemicals extensively thereby exposing them to health threatening doses. The most effective way to ameliorate these problems associated with agrochemical usage is to introduce agroforestry farming practice through the cultivation of agricultural crops with protected forest crops which will in turn provide more nitrogen to the soil and so lessen the need for agrochemical usage. In view of the above, it is imperative to know how agro forestry practice through taungya farming has impacted on the poverty and profitability status of adopters and non-adopters of taungya farming system in the study area. Specifically, the study aims at analyzing the socioeconomic characteristics of the farmers in the study area, to assess the poverty profile of adopters and non-adopters of taungya agro forestry system, and finally, to assess the profitability status of adopters and non-adopters of taungya farming system.

\section{MATERIAL AND METHODS}

The study area is Ogun State in South Western Nigeria. The state was created from the old western region in February, 1976 with Abeokuta as the state capital. The state has a land mass of about 1.7 million hectares and occupies about 1.9 percent of the total land area of Nigeria and has about 2.5 percent of the Nigerian population. It is made up of 20 Local Government Areas spread across the four main agricultural zones of the state- Egba, ljebu, Remo, and Yewa/Awori. Ogun state shares an international boundary with the Republic of Benin to the west and Oyo state to the north, Lagos state to the south, and Ondo state to the east.

The population of the state stands at 3.7million according to the National Population Commission of 2006. Ogun state lies within latitude $6^{\circ} \mathrm{N}$ and $7^{\circ} \mathrm{N}$ and $2.5^{\circ} \mathrm{E}$. There are two distinct seasons in the state namely, the rainy season and the dry season. Ogun state has two main types of vegetation, namely, tropical rain forest and the guinea savannah. The tropical rainforest is found in the coastal areas, majorly in Ogun waterside and part of the Yewa Local Government Areas. Rainforests are found in some parts of the ljebu zones of the state. Guinea and derived savannah are found in most of the western and northern parts of the state. The concentration of livestock production, poultry egg production in particular in these areas could be traceable to the perceived favourable characteristics of the vegetation in the area. The vegetation in the area is predominantly rainforest and derived savannah.

The research data were obtained through primary source with the aid of a wellstructured questionnaire from the rural farmers. Data were collected on the socio-economic characteristics such as age, gender, marital status, educational status, and a host of other variables. The taungya farming practices based in the forest reserves in the Agricultural Development Program zones of ljebu Ode and llaro were the focus of the paper. These 
forest reserves were Omo-Oshun (136,806 ha) in ljebu Ode ADP zone and Ilaro (4,608 ha), Ohunbe (4,608 ha) and Aworo (21,299 ha) in llaro ADP zone.

The sample size used for this study was 160 households. Multistage sampling technique was used for the selection. At stage one, two Agricultural Development Programme Zones - ljebu and llaro agro forestry taungya sites were purposively selected out of the four ADP zones in Ogun State. At stage two, $50 \%$ of the blocks were selected from each zone i.e. three blocks from ljebu and two blocks from llaro to give a total of five blocks. At stage three, four cells each per block were randomly selected to give twenty cells. At stage four, eight households were selected from each cell, which gave a total of one hundred and sixty (160) households from the study area.

A combination of analytical tools was employed during the course of this study. These include descriptive statistics, the Foster, Greer and Thorbecke (FGT) poverty index measures and the budgetary analysis. The descriptive analysis was used to depict the socioeconomic characteristics and it involved the use of tables, frequency and percentage proportions while the FGT poverty index developed by Foster et al. (1984), which has found wider application in scholarly works (Appleton, 1996; Ayinde et al., 2002; Olorunsanya and Omotesho, 2012) was adopted to assess the poverty status as related to the adopters and non adopters of taungya agro forestry. The model is a class of additively decomposable measure of poverty. The measure subsumes the headcount index and the poverty gap, and provides the distributional sensitive measure through the choice of a poverty aversion parameter percentage. The larger the value of the percentage, the greater the weight given by the index to the severity of poverty (Anyawu, 1997). The Foster, Greer and Thorbecke (FGT) poverty index measures were used to profile the poverty status of the adopters and non-adopters of taungya agro forestry practice using a seven days memory recall of the farmer expenditure on food and non-food expenses. The general specification of the model is as follows:

The FGT measure for the subgroup ith $P_{a i}$ is given as:

$$
\mathrm{P}_{\mathrm{ai}}=\frac{1}{\mathrm{n}} \sum_{\mathrm{j}=1}^{\mathrm{qi}}\left(\frac{\mathrm{z}-\mathrm{yij}}{\mathrm{z}}\right)^{\alpha}
$$

where:

$P_{\mathrm{ai}}=$ weighted poverty index for the $i^{\text {th }}$ subgroup;

$\mathrm{n}=$ total number of farmer households in the $\mathrm{i}^{\text {th }}$ subgroup

$\mathrm{y}_{\mathrm{ij}}=$ per capital expenditure of famer household $\mathrm{j}$ in sub-group $\mathrm{ij}$;

$\mathrm{Z}=$ the poverty line defined as $2 / 3$ of mean consumption per adult equivalent of the sampled population (FOS, 1999);

$\mathrm{z}-\mathrm{y}=$ is the proportionate shortfall below the poverty line

$q_{i}=$ the number of the sampled household heads below the poverty line

$\alpha=$ the aversion to poverty or degree of concern.

When $\alpha$ is equal to zero, it implies no concern and the equation gives the head count ratio for the incidence of poverty (the proportion of the farming household heads that are poor).

The poverty line used for this study is defined as the two-thirds of mean household per capita expenditure.

That is:

$$
\mathrm{P}_{\alpha i}=\frac{1}{n} \sum_{j=1}^{\mathrm{qi}}\left(\frac{\mathrm{z}-\mathrm{yij}}{\mathrm{z}}\right)^{\alpha}=\frac{\mathrm{qi}}{\mathrm{ni}} .
$$

when $\alpha$ is equal to 1 , it shows uniform concern and equation becomes:

$$
\mathrm{P}_{1 i}=\frac{1}{\mathrm{n}} \sum_{\mathrm{j}=1}^{\mathrm{qi}}\left(\frac{\mathrm{z}-\mathrm{yij}}{\mathrm{z}}\right)^{1}
$$

This measures the depth of poverty (the proportion of expenditure shortfall from the poverty line) according to Hall et al. (2005). It is otherwise called the poverty gap - the average difference between the income of the poor and the poverty line. When $\alpha$ is equal to 
2, distinction is made between the poor and the poorest (Assadzadeh et al., 2003). The equation becomes:

$$
\mathrm{P}_{2 i}=\frac{1}{\mathrm{n}} \sum_{\mathrm{j}=1}^{\mathrm{qi}}\left(\frac{\mathrm{z}-\mathrm{yij}}{\mathrm{z}}\right)^{1}
$$

The equation gives a distribution sensitive FGT index called the severity of poverty. It tells us the extent of the distribution of expenditure among the poor.

The FGT measure for the whole group or population was obtained using:

$$
\mathrm{P}_{\alpha}=\sum_{\mathrm{i}=1}^{\mathrm{m}} \frac{\mathrm{P \alpha ini}}{\mathrm{n}}
$$

where:

$P_{\alpha}=$ the weighted poverty index for the whole group

$\mathrm{m}=$ the number of subgroups;

$\mathrm{n}=$ total number of household heads in the whole group

$\mathrm{n}_{\mathrm{i}}=$ total number of household heads in the $\mathrm{i}^{\text {th }}$ sub-group

The contribution $\left(C_{i}\right)$ of each sub-group's weighted poverty measure to the whole group's weighted poverty measure was determined using:

$$
\mathrm{C}_{\mathrm{i}}=\frac{\mathrm{niP} \alpha \mathrm{i}}{\mathrm{nP} \alpha}
$$

The budgetary analysis was used to determine the cost and returns associated with the adopters and non-adopters of taungya farming system among cassava and maize based farmers, the budgetary analysis shows the net returns desirable from an enterprise after all the values of the inputs used have been deducted. The Gross margin was estimated, which is the difference between the Total Revenue and the Total Variable Cost. The mathematical notation for calculating the Gross margin is given by the equation below:

$$
G M=p_{i} y_{i}-r_{i} c_{i}
$$

where:

$\mathrm{GM}=$ Gross margin (naira)

$p_{i} y_{i}=$ Total revenue (naira)

$r_{i} c_{i}=$ Total variable cost (naira)

$\mathrm{p}_{\mathrm{i}}=$ Farm price of cassava and maize produce (naira)

$\mathrm{y}_{\mathrm{i}}=$ Output of cassava and maize produce $(\mathrm{Kg})$

$r_{i}=$ Price of variable input used (naira)

$\mathrm{C}_{\mathrm{i}}=$ Quantity of the variable input used $(\mathrm{Kg})$

Total variable cost (TVC)

$$
\mathrm{TVC}=\mathrm{X}_{1}+\mathrm{X}_{2}+\mathrm{X}_{3}+\mathrm{X}_{4}+\mathrm{X}_{5}+\mathrm{X}_{6}+\mathrm{X}_{7}
$$

where:

$\mathrm{X}_{1}=$ Cost of seedlings (naira)

$\mathrm{X}_{2}=$ Cost of fertilizers (naira)

$\mathrm{X}_{3}=$ Cost of labour (naira)

$\mathrm{X}_{4}=$ Cost of transport (naira)

$\mathrm{X}_{5}=$ Cost of herbicides (naira)

$\mathrm{X}_{6}=$ Cost of pesticides (naira)

$\mathrm{X}_{7}=$ other variable cost (naira)

Gross Margin = TR - TVC

Net Profit $=$ GM - TFC 
The difference of means was used to test whether there is significant difference in the net profit of adopters and non-adopters of taungya farming system. It was tested thus:

$$
\mathrm{T}=\frac{\mathrm{X}_{\mathrm{i}}-\mathrm{X}_{\mathrm{j}}}{\sqrt{\frac{\mathrm{s}_{\mathrm{i}}}{\mathrm{n}_{\mathrm{i}}}+\frac{\mathrm{s}_{\mathrm{j}}}{\mathrm{n}_{\mathrm{j}}}}}
$$

where:

$X_{i}=$ Mean net profit for the adopters

$X_{j}=$ Mean net profit for the non-adopters

$S_{i}=$ Sample variance for the adopter

$\mathrm{S}_{\mathrm{j}}=$ Sample variance for the non-adopters

$n_{i}=$ Number of adopters

$n_{j}=$ Number of non-adopters

\section{RESULTS AND DISCUSSION}

Majority of the farmer respondents in the study are males. The distribution was (78\%) males among the adopters and (42\%) males among the non-adopters, which imply that more males are engaged in taungya farming in the study area. The socio-economic table shows that only few people fall within the age range of 30 years and below $(6 \%$ adopters and $10 \%$ non-adopters). The low participation of women in the study area (22\% female adopters and $13 \%$ female non-adopters) may stem from the incapability of women to pay for the initial high labour costs for land clearing since women make up to $60 \%$ of the world's poor (ILO, 2004) as reaffirmed in 2006.

The manual nature of taungya farming requires large households that can share labour for agricultural production to enhance their expanded farm operations. The socio-economic table shows that the household size for adopters is between $10-14$ people about $39 \%$ of the population, while for non-adopters is between $5-9$ people about $25 \%$ of the population. Therefore, adopters households are most likely to participate more meaningfully in taungya farming since there will be division of labour because of their large household size, coupled with the capabilities and quality of the household members. The low level educational status of the respondents is likely to impair the adoption of taungya innovations. This is because an unskilled population has the potential of impairing labour mobility. It can be shown from the above table that $45 \%$ of adopters and $25 \%$ of non- adopters had no formal education, while $4 \%$ and $1 \%$ of the adopters and non-adopters respectively had tertiary education.

The result of the survey further shows that ( $41 \%$ of adopters and $41.8 \%$ of nonadopters) farmers respectively had between $10-19$ years of taungya farming experience and less than 10 years non taungya farming experience respectively. The years of experience of the taungya farmers is supposed to have a positive influence on the production efficiency of the farmers ceteris paribus. This study revealed that $44 \%$ and $23 \%$ of both adopters and non-adopters respectively had between $1.1-1.5$ (ha) of farm land. Furthermore, $33 \%$ and $16 \%$ of both adopters and non-adopters respectively had between 0.5 - 1.0(ha) of farm land for cultivation. All things being equal, the more farmlands farmers possess, the greater the potential to increase food crops.

Webster (1990) has also indicated that poverty in the Third World is substantially due to a steady decline in available land particularly in the rural sector. Thus, increase in land holdings for both adopters and non-adopters would lead to a sharp decrease in relative deprivation for the rural family and also has the potential to improve food production, increase income and ultimately reduce their poverty level.

From table 1, the monthly income of the respondents varies from one party to another (i.e. adopters and non-adopters). The adopters of taungya farming were of higher monthly income bracket as 39\% earned between N10,000.00 - N50,0000.00 per month as compared to the $29.1 \%$ of the non adopters in this income category. This portends a lower poverty status for non adopters of taungya agro forestry. 
Table 1 - Socio-economic characteristics of the respondents

\begin{tabular}{|c|c|c|c|c|}
\hline \multirow{2}{*}{ Variable } & \multicolumn{2}{|c|}{ Adopters } & \multicolumn{2}{|c|}{ Non-adopters } \\
\hline & Frequency & Percentage & Frequency & Percentage \\
\hline \multicolumn{5}{|l|}{ Age } \\
\hline Less than 30 & 6 & 6.0 & 10 & 18.2 \\
\hline $30-39$ & 17 & 17.0 & 12 & 21.8 \\
\hline $40-49$ & 32 & 32.0 & 19 & 34.5 \\
\hline $50-59$ & 24 & 24.0 & 4 & 7.3 \\
\hline $60-69$ & 14 & 14.0 & 7 & 12.7 \\
\hline 70 and above & 7 & 7.0 & 3 & 5.5 \\
\hline \multicolumn{5}{|l|}{ Gender } \\
\hline Male & 78 & 78.0 & 42 & 76.4 \\
\hline Female & 22 & 22.0 & 13 & 23.6 \\
\hline \multicolumn{5}{|l|}{ Household size } \\
\hline Less than 5 & 10 & 10.0 & 25 & 45.5 \\
\hline $5-9$ & 33 & 33.0 & 14 & 25.5 \\
\hline $10-14$ & 39 & 39.0 & 10 & 18.2 \\
\hline $15-19$ & 15 & 15.0 & 5 & 9.1 \\
\hline 20 and above & 3 & 3.0 & 1 & 1.8 \\
\hline \multicolumn{5}{|l|}{ Education } \\
\hline No formal & 45 & 45.0 & 25 & 45.5 \\
\hline Primary & 25 & 25.0 & 13 & 23.6 \\
\hline Secondary & 26 & 26.0 & 16 & 29.1 \\
\hline Tertiary & 4 & 4.0 & 1 & 1.8 \\
\hline \multicolumn{5}{|l|}{ Farming experience } \\
\hline Less than 10 & 21 & 21.0 & 23 & 41.8 \\
\hline $10-19$ & 41 & 41.0 & 15 & 27.3 \\
\hline $20-29$ & 19 & 19.0 & 8 & 14.5 \\
\hline $30-39$ & 13 & 13.0 & 5 & 9.1 \\
\hline 40 and above & 6 & 6.0 & 4 & 7.3 \\
\hline \multicolumn{5}{|l|}{ Farm size } \\
\hline $0.5-1.0$ & 33 & 33.0 & 16 & 29.1 \\
\hline $1.1-1.5$ & 43 & 43.0 & 23 & 41.8 \\
\hline $1.6-2.0$ & 8 & 8.0 & 10 & 18.2 \\
\hline $2.1-2.5$ & 10 & 10.0 & 5 & 9.1 \\
\hline 2.6 and above & 5 & 5.0 & 1 & 1.8 \\
\hline \multicolumn{5}{|l|}{ Marital status } \\
\hline Married & 64 & 64.0 & 40 & 72.7 \\
\hline Single & 18 & 18.0 & 4 & 7.3 \\
\hline Divorced & 2 & 2.0 & 6 & 10.9 \\
\hline Widowed & 6 & 6.0 & 5 & 9.1 \\
\hline \multicolumn{5}{|l|}{ Farming income } \\
\hline Less than 10000 & 1 & 1.0 & 6 & 10.6 \\
\hline $10000-30000$ & 20 & 20.0 & 12 & 21.8 \\
\hline $31000-50000$ & 19 & 19.0 & 4 & 7.3 \\
\hline $51000-70000$ & 9 & 9.0 & 5 & 9.1 \\
\hline 71000 and above & 51 & 51.0 & 28 & 50.9 \\
\hline
\end{tabular}

Source: Computed from field survey data, 2014.

The Foster Greer Thorbecke (FGT) analysis was used in determining the poverty profile of the adopters and non-adopters of taungya agro forestry system, bearing in mind the socio-economic characteristics of the sampled farmer households. Table 2 showed that the poverty incidence was most noticed among the non-adopters of taungya agro-forestry $(45.4 \%)$. Furthermore, this study showed that (30.1) percent and (45.4) percent of the adopters and non-adopters of taungya farming respectively falls below the poverty line. The poverty depth and severity of the adopters and non-adopters of taungya farming are $(6.8 \%)$ and $(0.4 \%)$ and $(26.3 \%)$ and $(6.9 \%)$ respectively in that order. This implies that 6.8 and 26.3 percents of the adopters and non-adopters fall short of the poverty line respectively. It also implies that with poverty line established at $\$ 2627.59$ per week, what is required to get each adopter and non-adopter out of poverty is $\$ 178.64$ and $\$ 691.04$ respectively. The poverty severity of the adopters and non-adopters was calculated as 0.4 and 6.9 percents 
respectively. These represent percentages of taungya agro forestry adopters and nonadopters that are core poor.

Table 2 - Poverty profile of adopters and non-adopters of taungya farming system

\begin{tabular}{|l|l|l|l|l|l|}
\hline \multicolumn{1}{|c|}{ Categories } & \multicolumn{1}{c|}{$\mathrm{P}_{0}$} & \multicolumn{1}{c|}{$\mathrm{P}_{1}$} & \multicolumn{1}{c|}{$\mathrm{P}_{2}$} & $\mathrm{Q}$ & $\mathrm{N}$ \\
\hline Adopters & 0.301 & 0.0688 & 0.0047 & 30 & 100 \\
\hline Non-adopters & 0.4545 & 0.263 & 0.069 & 25 & 55 \\
\hline Pooled & 0.354 & 0.135 & 0.018 & 55 & 155 \\
\hline
\end{tabular}

Source: Computed from field survey data, 2014.

Table 3 - Test of difference of mean between the poverty incidence, depth and severity of the adopters and non-adopters of taungya farming system

\begin{tabular}{|l|l|l|l|}
\hline \multicolumn{1}{|c|}{ Categories } & \multicolumn{1}{c|}{ Standard error } & \multicolumn{1}{c|}{$\mathrm{n}$} & \multicolumn{1}{c|}{ T-ratio } \\
\hline Adopters (Incidence) & 118957.026 & 100 & $3.271^{*}$ \\
\hline Non-adopters(Incidence) & 86245.953 & 55 & \\
\hline Adopters (Gap) & 1.743876 & 100 & $2.47^{* *}$ \\
\hline Non-adopters(Gap) & 0.670056 & 55 & $-4.78^{*}$ \\
\hline Adopters (Severity) & 2.76491 & 100 & \\
\hline Non-adopters(Severity) & 1.54900 & 55 & \\
\hline
\end{tabular}

Source: Computed from field survey data, 2014.

The decomposition of the poverty status according to sub-groups was shown on Table 4 and Table 5; the adopter's age sub-group showed that the poverty incidence was highest among the 70 and above age group at 57.1 percent, which implies that 57.1 percent of the adopters within this age group fall below the poverty line. Furthermore, the poverty depth was 1.3 percent which means 1.3 percent of the adopters fall short of the poverty line, also 0.017 percent of them were core poor. Also, the age-group less than 30 had the lowest incidence rate of poverty at 16.0 percent, which implies that 16.0 percent of the adopters that fall within this age group are below the poverty line. Whereas the poverty depth and severity of this age group is 0.17 and 0.000289 percent respectively.

For the non-adopters age sub-group, it was shown that the $50-59$ age groups had the highest poverty incidence at 0.8 percent, and a poverty depth and severity of 5.1 and 0.26 percent. This implies that 0.8 percent of the non-adopters within this age group fall below the poverty line. Also the poverty depth which is 5.1 percent means 5.1 percent of the nonadopters fall short of the poverty line and 0.26 percent of them were core poor. Also, the agegroup 60 - 69 had the lowest incidence rate of poverty at 28.5 percent, which implies that 28.5 percent of the non- adopters that fall within this age group are below the poverty line. Whereas the poverty depth and severity of this age group is 2.4 and 0.0605 percent respectively.

The decomposition with regards to income of the adopters sub-group revealed that the $10000-30000$ earners had the highest poverty incidence of 36.8 percent, which implies that 36.8 percent of this group falls below the poverty line. Furthermore, the poverty depth and severity of this group was 0.2 and 0.000441 percent. Also 21.0 percent of the $31000-50000$ income earners had the lowest poverty incidence, which means 21.0 percent of this group fall below the poverty line. With respect to the non-adopters income sub-group, 21.0 percent of the 71000 and above income earners had the lowest poverty incidence, which implies that 21.0 percent fall below the poverty line.

The decomposition with respect to educational status sub-group revealed that among the adopters, those with no formal education have the highest poverty incidence of 33.3 percent, which implies that 33.3 percent of this group fall short the poverty line, with a poverty depth and severity of 4.3 and 0.00186 percent respectively, which implies that 4.3 percent of this group fall short the poverty line and 0.186 percent are core poor. Also 25.0 percent of the adopters that posses tertiary education has the lowest poverty incidence rate, which implies that 25.0 percent of this group fall below the poverty line, with a depth and severity of 0.000907 and $8.22 \mathrm{E}-08$ percent respectively. With respect to the non-adopters 
educational subgroup, only 1.0 percent of those with tertiary education has the highest poverty incidence, which implies that 1.0 percent of this group fall short the poverty line and also with a depth and severity of 1.1 and 0.0132 percent respectively. Furthermore, 36.0 percent of the non-adopters educational sub-group had the lowest poverty incidence with a depth and severity of 10.5 and 1.1 percent respectively in terms of no formal education.

Table 4 - Poverty profile of sub-group based on socio-economic characteristics of adopters and nonadopters of taungya farming system

\begin{tabular}{|c|c|c|c|c|c|}
\hline Categories & $\mathrm{P}_{0}$ & $\mathrm{P}_{1}$ & $\mathrm{P}_{2}$ & $q$ & $n$ \\
\hline \multicolumn{6}{|l|}{ Age (Adopters) } \\
\hline Less than 30 & 0.16 & 0.0017 & 0.00000289 & 1 & 6 \\
\hline $30-39$ & 0.29 & 0.0096 & 0.0000222 & 5 & 17 \\
\hline $40-49$ & 0.21 & 0.0221 & 0.0001 & 7 & 32 \\
\hline $50-59$ & 0.29 & 0.0117 & 0.000136 & 7 & 24 \\
\hline $60-69$ & 0.42 & 0.0117 & 0.000136 & 6 & 14 \\
\hline 70 and above & 0.571 & 0.0133 & 0.00017 & 4 & 7 \\
\hline \multicolumn{6}{|l|}{ Age (Non-Adopters) } \\
\hline Less than 30 & 0.6 & 0.011 & 0.00012 & 6 & 10 \\
\hline $30-39$ & 0.538 & 0.0573 & 0.00328 & 7 & 13 \\
\hline $40-49$ & 0.33 & 0.063 & 0.00396 & 6 & 18 \\
\hline $50-59$ & 0.8 & 0.051 & 0.0026 & 4 & 5 \\
\hline $60-69$ & 0.285 & 0.0246 & 0.000605 & 2 & 7 \\
\hline 70 and above & 0 & 0 & 0 & 0 & 2 \\
\hline \multicolumn{6}{|c|}{ Age (Pooled Sampled Farmers) } \\
\hline Less than 30 & 0.437 & 0.179 & 0.032 & 7 & 16 \\
\hline $30-39$ & 0.4 & 0.048 & 0.0023 & 12 & 30 \\
\hline $40-49$ & 0.26 & 0.86 & 0.739 & 13 & 50 \\
\hline $50-59$ & 0.37 & 0.73 & 0.532 & 11 & 29 \\
\hline $60-69$ & 0.38 & 0.009 & 0.00008 & 8 & 21 \\
\hline 70 and above & 0.44 & 0.006 & 0.444 & 4 & 9 \\
\hline \multicolumn{6}{|c|}{ Monthly Income (Non-Adopters) } \\
\hline Less than 10000 & 0 & 0 & 0 & 0 & 4 \\
\hline $10000-30000$ & 0.368 & 0.0021 & 0.00000441 & 7 & 19 \\
\hline $31000-50000$ & 0.21 & 0.0126 & 0.000158 & 4 & 19 \\
\hline $51000-70000$ & 0.333 & 0.0095 & 0.0009 & 3 & 9 \\
\hline 71000 and above & 0.2653 & 0.0188 & 0.00035 & 13 & 49 \\
\hline \multicolumn{6}{|c|}{ Monthly Income (Non-Adopters) } \\
\hline Less than 10000 & 1 & 0.0712 & 0.00506 & 6 & 6 \\
\hline $10000-30000$ & 0.66 & 0.0828 & 0.00685 & 8 & 12 \\
\hline $31000-50000$ & 0.5 & 0.0126 & 0.00015 & 2 & 4 \\
\hline $51000-70000$ & 0.6 & 0.0398 & 0.00158 & 3 & 5 \\
\hline 71000 and above & 0.21 & 0.056 & 0.00313 & 6 & 28 \\
\hline \multicolumn{6}{|c|}{ Monthly Income(Pooled sampled farmers) } \\
\hline Less than 10000 & 0.6 & 0.113 & 0.0127 & 6 & 10 \\
\hline $10000-30000$ & 0.48 & 0.044 & 0.0019 & 15 & 31 \\
\hline $31000-50000$ & 0.26 & 0.179 & 0.032 & 6 & 23 \\
\hline $51000-70000$ & 0.42 & 0.032 & 0.0012 & 6 & 14 \\
\hline 71000 and above & 0.24 & 0.086 & 0.00739 & 19 & 77 \\
\hline
\end{tabular}

Source: Computed from field survey data, 2014.

The budgetary analysis was used to determine the net profit/ha of both adopters and non-adopters of taungya farming system. The breakdown of the costs and returns can be

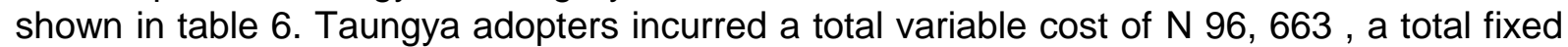
cost of N128, 378 and earned a total revenue of N474,368 per hectare. Furthermore, adopters had an average net profit of N249,327/ha while for the non-adopters was $\mathrm{N} 167,391.00 /$ ha on an average of 1.05 hectares of land. 
Table 5 - Poverty profile of sub-group based on socio-economic characteristics of adopters and nonadopters of taungya farming system

\begin{tabular}{|c|c|c|c|c|c|}
\hline \multicolumn{4}{|c|}{ Categories $\mathrm{P}_{0} \mathrm{P}_{1} \mathrm{P}_{2}$} & q & $\mathrm{n}$ \\
\hline \multicolumn{6}{|c|}{ Educational status (Adopters) } \\
\hline No formal & 0.333 & 0.0432 & 0.00186 & 15 & 45 \\
\hline Primary & 0.28 & 0.016 & 0.00025 & 7 & 25 \\
\hline Secondary & 0.26 & 0.0094 & 0.00008 & 7 & 26 \\
\hline Tertiary & 0.25 & 9.07E-05 & $8.22 \mathrm{E}-09$ & 1 & 4 \\
\hline \multicolumn{6}{|c|}{ Educational status (Non-Adopters) } \\
\hline No formal & 0.36 & 0.105 & 0.011 & 9 & 25 \\
\hline Primary & 0.46 & 0.056 & 0.00313 & 6 & 13 \\
\hline Secondary & 0.56 & 0.0896 & 0.00802 & 9 & 16 \\
\hline Tertiary & 1 & 0.0115 & 0.000132 & 1 & 1 \\
\hline \multicolumn{6}{|c|}{ Educational status (Pooled sampled farmers) } \\
\hline No formal & 0.342 & 0.084 & 0.007 & 24 & 70 \\
\hline Primary & 0.342 & 0.022 & 0.0004 & 13 & 38 \\
\hline Secondary & 0.38 & 0.044 & 0.0019 & 16 & 42 \\
\hline Tertiary & 0.4 & 0.023 & 0.00052 & 2 & 5 \\
\hline
\end{tabular}

Source: Computed from field survey data, 2014.

Table 6 - Cost and returns associated with the adopters and non-adopters of taungya farming (Maize and Cassava/ha)

\begin{tabular}{|l|l|l|l|l|}
\hline \multirow{2}{*}{ Cost Items } & \multicolumn{2}{c|}{ Adopters } & \multicolumn{2}{c|}{ Non-Adopters } \\
\cline { 2 - 5 } & Amount (Naira) & Cost Percentage & Amount (Naira) & Cost Percentage \\
\hline Total Revenue( $(\mathbb{N})$ & 474,368 & 390,800 \\
\hline Total Variable Cost & 15,549 & 16.08 & 24,379 & 23.91 \\
\hline Fertilizer & 9,850 & 10.19 & 8,900 & 8.73 \\
\hline Seedlings & 2,231 & 2.3 & 1,990 & 1.95 \\
\hline Transportation & 9,478 & 9.8 & 10,500 & 10.3 \\
\hline Labour & 16,790 & 17.36 & 18,450 & 17.36 \\
\hline Herbicides & 3,683 & 3.8 & 2,750 & 2.69 \\
\hline Planting Cost & 22,659 & 23.44 & 20,650 & 20.26 \\
\hline Implements & 16,423 & 16.98 & 14,300 & 14.03 \\
\hline Others & $\mathrm{N} 96,663$ & 100.00 & $\mathrm{~N} 101,919$ & 100.00 \\
\hline Total Variable Cost & $\mathrm{N} 377,705 / \mathrm{ha}$ & $\mathrm{N} 288,881.00 / \mathrm{ha}$ \\
\hline Gross Margin & $\mathrm{N} 128,378$ & $\mathrm{~N} 121,490$ & \\
\hline Total Depreciated Fixed Cost & $\mathrm{N} 225,041$ & $\mathrm{~N} 223,409$ & \\
\hline Total Cost & $\mathrm{N} 249,327 / \mathrm{ha}$ & $\mathrm{N} 167,391 / \mathrm{ha}$ \\
\hline Net Profit & 1.10 & 0.749 \\
\hline Rate of Return on Investment & \multicolumn{3}{l}{} \\
\hline
\end{tabular}

Source: Computed from Field Survey Data, 2014.

Table 7 - Test of difference of mean between the net profit/ha of the adopters and non-adopters

\begin{tabular}{|l|l|l|l|l|c|}
\hline \multicolumn{1}{|c|}{ Categories } & \multicolumn{1}{c|}{ Mean } & \multicolumn{1}{c|}{ Standard Error } & $\mathrm{n}$ & \multicolumn{1}{c|}{ T-value } & sig. \\
\hline Adopters & 1.611795 & 0.131788 & 100 & $19.896^{\star \star}$ & 0.05 \\
\hline Non-Adopters & 1.027115 & 0.011321 & 55 & & \\
\hline
\end{tabular}

Source: Computed from field survey data, 2014.

A total variable cost of $\mathrm{N} 101,919$ was incurred by the non-adopters with a total fixed cost of $\mathrm{N} 121,490.00$ and earned a total revenue of N390,800. For the adopters the cost of fertilizer application was 16.09 percent of the total variable cost, which was lower compared to the non-adopters, which was 23.91 percent of the total variable cost. The lower usage of fertilizer by the adopters could have emanated from the inorganic matter from decomposed tree trunks, and litter fall, which serves has manure and inorganic fertilizer, thereby reducing the cost on fertilizer application. The Total Fixed Cost was depreciated using the straight line method; the total fixed cost for the adopters was N128, 378, while that of the non-adopters was $\mathrm{N} 121,490$. The rate of return on investment values of 1.10 for the adopters and 0.749 
for the non-adopters means that for every one naira invested by the adopters and nonadopters in cassava and maize production respectively in the study area will yield a net profit of $\mathrm{N} 1$ and $74 \mathrm{kobo}$ to the farmers respectively. The t-test of difference of mean was used to determine the extent of the difference in the net profit/ha of the adopters and non-adopters. The result of the t-test of difference of mean net farm income for adopters was significant $(p<0.05)$, which shows that there is a significant difference between the net profit of the adopters and non-adopters. The t-value result which was significant at 5 percent level implies that we reject the null hypothesis and thus fail to reject the alternate hypothesis.

\section{CONCLUSIONS}

The socio-economic characteristics show that majority of the farmers - adopters and non-adopters were male with small farm areas and high household sizes that ensured ready availability of labour for farming. Education and income seemed to have influenced adoption of taungya system as much educated and well to do farmers were in this practice.

This study revealed a marked difference in the poverty status of both adopters and non-adopters of taungya farming system; it was showed that the poverty incidence was highest among the non-adopters, which implies that farmers adopting taungya farming system are better off in terms of welfare than farmers that are not adopting. This is possible because adopters of taungya farming has the potential of generating higher yield which could have emanated from the inorganic matter from decomposed tree trunks, and litter fall. The differential in yields is likely to encourage non-adopters to adopt taungya farming so as to realize the benefit of increased productivity to offset the high cost of food production grain translating into more months of food availability (food security) at the household as well as enjoying higher standards of living resulting from increased farm income. Therefore, taungya farming should be encouraged to increase rural farmers' income, and alleviate poverty.

Policy instrument that encourages sustainable practices in food crop production through taungya farming system should be put in place, so as to reduce the usage of agrochemicals on farmland and at the same time increasing rural farmer's income. This will not only take care of agricultural productivity alone, but will also improve the economic and environmental aspirations of the people.

\section{REFERENCES}

1. AfDB/OECD. (2008): African economic outlook 2008: Ghana. Ghana (Africa): African Development Bank Group. p. 331-344. Available from: http://www.afdb.org

2. Anyanwu, J. C. (1997): "Poverty in Nigeria: Concepts, Measurement and Determinants."In: Poverty Alleviation in Nigeria. Proceedings of the 1997 Annual Conference of the Nigerian Economic Society (NES). Ibadan: NES, pp. 93-120.

3. Appleton, S., 1996: Women-headed households and household welfare: An empirical deconstruction for Uganda. World Dev., 24(12): 1811-1827.

4. Ayinde, O. E., Ajewole, O. O., Ogunlade, I. and Adewumi, M.O. Empirical Analysis of Agricultural Production And Climate Change: A Case Study of Nigeria. Journal of Sustainable Development in Africa (Volume 12, No.6, 2010)

5. Assadzadeh, A. and S. Paul, (2003): Poverty Growth and Redistribution. A case Study of Iran, Eds. Rolph Vander Hoeven and Anthony Sherrocks, Perspective on Growth and Poverty, UNU/WIDER: Helsunki, Finland.

6. FOS (Federal Office of Statistics), (1999): Nigeria Living Standard Survey 2003/2004. Report prepared by Federal Office of Statistics in collaboration with European Union, World Bank, Department for International Studies.

7. Foster, J., J. Greer and E. Thorbecke, (1984): A class of decomposable poverty measures. Econometrica, 52(3): 761-766.

8. Hall, G. and H.A. Patrinos, (2005): "Latin America's Indigenous People”. Latin America. A Time of Transition, Finance and Development. International Monetary Fund, 42: 24.

9. ILO (2004): Intensive Care for the Job market. World of Work No 10, 2004. 
10. Jordan, C.F. Gajaseni J., Watanabe H., (1992): Taungya: Forest Plantations with Agriculture in Southeast Asia (eds) CAB International, Wallingford, Oxon Ox 10 RDE UK.

11. Kuponiyi, F.A., \& Adewale, J.G. (2008): The use of safety devices in adoption of agrochemicals by rice farmers in Obafemi-Owode Local Government Area of Ogun State. African Journal of Food, Agriculture, Nutrition and Development, 8(4), 427-440.

12. MEA. (2003): Ecosystems and Human Well-being. Millennium Ecosystem Assessment. Island Press, Washington DC, USA.

13. Nair, K. (1993): An Introduction to Agroforestry. Kluver Academic publishers 499p.

14. Olorunsanya, E., O. and Omotesho, O., A.(2012): A Gender Analysis of Poverty among Rural Farming Households in North Central Nigeria. European Journal of Social Sciences ISSN 1450-2267 Vol.28 No.3, pp. 366-376.

15. Pretty J, Noble A, Bossio D, Dixon J, Hine R E, Penning de Vries P and Morison J I L. (2006): Resource conserving agriculture increases yields in developing countries. Environmental Science and Technology 40 (4), 1114 -1119.

16. UNFCCC (2010): Implementation Plan for the Global Observing System for Climate in Support of the UNFCC.

17. Webster, A. (1990): An introduction to sociology of development. (2nd ed.), London: Palgrave Macmillan. 